\title{
MicroRNA's in cancer as biomarkers and therapeutic keys
}

\author{
Sindhuja Sreedharam, Vinayaga Moorthi Puthamohan ${ }^{*}$ and Sona Valiya Parambil
}

\begin{abstract}
MicroRNA (miRNA), the noncoding RNAs, are short length with 22 nucleotides. It involved in various biological process. Its expression is found varied in cancer and hence used as a marker. miRNAs are become important entity that changes the expression of genes in disease particularly cancer. In this review, different types of miRNAs were addressed with its relationship in different types of cancer. The level of expression miRNA is depends upon the different stages and could be used as a marker for early diagnosis. The circulating as well as exosome miRNA in cancer was also discussed. This review could facilitates us to study the miRNA as biomarker and it additionally paves way for therapeutic approaches.
\end{abstract}

\section{Background}

A couple of decades ago, provenances of microRNA (miRNA) discovery lead to the new arena in molecular biology. In humans, more than 2000 miRNAs were discovered and it regulate more than $25 \%$ of the genes. It's often well connected with various diseases and hence they are useful for diagnosis [1]. miRNAs, the noncoding RNAs, are short length with nearly twenty two nucleotides. It is found in eukaryotes and they are part of all pathways in our biological system [2]. It controls the cellular process such as cell cycle, inflammation, cell differentiation and cell death, through inhibition of mRNAs stability and translation. Hence, this miRNAs are inevitable in all biological process and signaling in a cell. Its dysregulation is often leads to genesis of cancer [3].

The first miRNA was discovered in the year 1993 and was outcome of the two different studies reported Lin-4 as small non coding RNA from Ceanorhabditis elegans heterochronic gene lin-4 [4]. At that time, this small non coding RNA was considered as a specific tool used by the worms to manage their heterochronic gene expressions. After 7 years, Reinhart et al. [5] other small ncRNAs in $C$. elegance represented Let-7, the heterochronic gene. They together with lin-4 RNA were initiating the cascades of

\footnotetext{
* Correspondence: vinayputhu@gmail.com

Department of Human Genetics and Molecular Biology, Bharathiar University, Coimbatore 641 046, Tamil Nadu, India
}

heterochronic genes regulation via RNA-RNA interaction at $3^{\prime}$ untrasnlated region of the gene target [5]. It lead to trace the other small ncRNA and it unveiled the existence of ncRNAs in different organisms in which it plays as potential regulatory control and then named as microRNAs [6-8]. Later it was identified that they are all inhabitant of plants, animals and now miRNA database revealed a total of 2042 and 1281 mature RNAs in human and mouse respectively [9]. In mammals, miRNAs genes have paralogue, i.e., different isoforms while it is well conserved in animals. There were 8 isoforms were existing in 11 genomic loci. Interestingly, in C. elegans almost 55\% of the miRNAs were found similar to humans. The majority of miRNA gene occupy regions away from annotated gene often due to one transcriptional unit. Over $50 \%$ of the miRNA genes are clustered and normally transcribed as multcistronic RNA transcript. In animals, it constitute a gene regulatory molecule and had impact on gene expression and thus in cancer it exert unique role in phenotype of the disease [3]. In cancer, miRNA play a role in disease initiation, movement of cell from site of origin, disease prognosis and response during treatment [10].

\section{Main text \\ Biogenesis \\ The biogenesis of miRNA starts with the formation of pri-miRNA, the long transcript. The RNA polymerase II}

(c) The Author(s). 2020 Open Access This article is licensed under a Creative Commons Attribution 4.0 International License, which permits use, sharing, adaptation, distribution and reproduction in any medium or format, as long as you give appropriate credit to the original author(s) and the source, provide a link to the Creative Commons licence, and indicate if changes were made. The images or other third party material in this article are included in the article's Creative Commons licence, unless indicated otherwise in a credit line to the material. If material is not included in the article's Creative Commons licence and your intended use is not permitted by statutory regulation or exceeds the permitted use, you will need to obtain permission directly from the copyright holder. To view a copy of this licence, visit http://creativecommons.org/licenses/by/4.0/. 
transcribe the pri-miRNA and keep the mRNA with all its features (5' Cap and 3' Poly(A) tail) [11, 12]. Similarly, genomic repeats also generate set of miRNAs through other pathways i.e., In Alu repeats, the RNA polymerase III transcribe the miRNA [13]. Pri-miRNA to pre-miRNA formation occurs in nucleus with the help of RNase III (Drosha) and DGCR8, its partner [14-16]. DGCR8 generate the pre-miRNA, hairpin shaped, by cutting the stem from stem-ssRNA junction $[17,18]$.

\section{Biological roles Of miRNAs}

The Dicer and DGCR8 deficient mouse model are the first initiative to explore the significance of miRNAs in developmental stages of mammals since biogenesis of miRNA associated with DGCR8. Break in any of the step in biogenesis of miRNA is found leathal to embryo [19, 20]. Its, any of the genes, loss of function in tissues also causes developmental dysfunction in associated tissues [21]. Mouse models with miRNA knockout already demonstrated its, the genes, role in all tissue type and its associated developmental defects [21, 22].

\section{Dysregulation of miRNAs}

Literatures portray the existence of miRNA role either in up-regulation or down regulation in diseases experienced by human. MiRNA dysregulation often thought to be linked with one of the factor in progression of disease. In cancers, its altered expressions were highly reported [1]. The list of miRNA's expressed in breast, esophageal and gastric caner are listed in Table 1.

\section{Cancer}

\section{Breast cancer}

Oncogenic miRNA In cancer, upregulation of oncogenic miRNA was frequently noticed and they deliver its action through suppressing the tumor suppressor gene that regulates the normal cell regulatory and cleaning process such as apoptosis etc. [42]. The following are the some of the miRNAs recorded in breast cancers.

miR-10 family miR-10a, $10 \mathrm{~b}$ are the members of miR10 family resides in Hox cluster. In murine xenograft breast cancers model, miR-10b is, found over expressed, inducing metastasis and invasion through HOXD10 gene [23]. Its expression level was found positively associated with all clinical features such as size of the tumor, proliferation, stages, metastasis while it is negatively associated with $\mathrm{PR}^{+}, \mathrm{ER}^{+}$and level of E-cadherin. Its, miR-10b, transcription factor enhances invasion and metastatic ability through HOXD10 in cell lines and animal models $[23,43,44]$.

miR - 21 It is also involved in breast cancer cell migration and invasion [45, 46]. Chan et al. recorded higher
miR-21 level in tumor tissue of human glioblastoma and generated cell line out of it. It helped them to compare it with brain tissues of fetal and adult non neoplastic tissues [24]. Besides miR-21, miR-125b, 145, 155 expressions were also noticed aberrantly in breast cancer [47]. Its, miR-21, upregulation is found correlated with increasing in grade of the tumor, status of the receptors of hormones and ductal carcinoma.

miR-17-92 A polycistron, comprising mature miR-18b, 19b, 20a, 92, 93, 106 [48]. miR-17-5p is found elevated in invasive breast cancer cells (MDA-MB-231) while not expressed in MCF-7 (non invasive) cells. miR-17-5p target the HBP1-beta catenin pathway in MCF-7 cell to perform as highly invasive and migratory when ectopically expressed while this miRNA, in in vitro, is suppressing the MDA-MB-231 cell and inhibit the cell migration and invasion [25].

Tumor suppressor In C. elegans embryogenesis importance of let-7 family in determination of cell type was noticed by Reinhart et al. [49]. It consists of let-7a-g, miR98 and miR-202. It involved in various physiological such as development, cell adhesion, muscle formation and gene expression regulation. Let-7 family is found lost during early disease progression stage in breast cancer [28].

miR-200 family It consists of miR-200a, 200b, 200c, 141 and miR-429. These are EMT suppressors [50-52]. They were found lost in mesenchymal phenotypic cell lines of invasive breast cancer. The drug resistances found in human breast cancers were found linked to miR-200 down regulation [27].

miR-205 It is found down regulated in triple negative breast cancer cell $[26,52]$. Its expression prevents the growth and development of the breast cancer cell. Triple negative breast cancer cell can be protected by miR-205 as tumor suppressor. Its expression supports the inhibition of different physiological mechanisms of the cell in in vitro and in vivo.

miR-145 It is found down regulated in breast cancer tissues compared to normal breast tissue in a study by Iorio et al. [47]. It is often used as early diagnostic biomarker due to its expression pattern in breast cancer $[28,53]$.

\section{Esophageal cancer Oncogenic miRNA miR-21}

It, used for the ESCC prognosis, has strong relationship with development of EAC and ESCC. In many 
Table 1 microRNA expressions in different cancer cell/tumor

\begin{tabular}{|c|c|c|c|c|c|c|}
\hline S. NO. & miRNA & REGULATION & CANCER & ROLE & AUTHOR & \\
\hline 1 & miR-10b & Up-regulated & $\begin{array}{l}\text { Metastatic - Breast Cancer } \\
\text { cells }\end{array}$ & $\begin{array}{l}\text { Cell migration and Invasion nin } \\
\text { Murine Xenograft }\end{array}$ & [23] & \multirow[t]{10}{*}{ Breast Cancer } \\
\hline 2 & miR-21 & Up-regulated & $\begin{array}{l}\text { Human Glioblastoma Tumor } \\
\text { Tissue }\end{array}$ & $\begin{array}{l}\text { Aggressive disease status: High } \\
\text { tumor grade, negative hormone } \\
\text { receptor status and ductal carcinoma }\end{array}$ & [24] & \\
\hline 3 & miR-17-5p & Up-regulated & $\begin{array}{l}\text { MDA-MB-231 Breast Cancer } \\
\text { Cells }\end{array}$ & - & [25] & \\
\hline 4 & miR-205 & Up-regulated & Breast Cancer cells & $\begin{array}{l}\text { Prevents invasion, Proliferation and } \\
\text { anchorage independent growth }\end{array}$ & {$[26]$} & \\
\hline 5 & miR-17-5p & Down-regulated & $\begin{array}{l}\text { MDA-MB-231 Breast Cancer } \\
\text { Cells }\end{array}$ & Migration and Invasion & {$[25]$} & \\
\hline 6 & miR-200 & Down-regulated & $\begin{array}{l}\text { Invasive Breast cancer cells } \\
\text { lines with mesenchymal } \\
\text { phenotype }\end{array}$ & Drug resistance in Human Breast cancer & {$[27]$} & \\
\hline \multirow[t]{2}{*}{7} & miR-145 & Down Regulated & Breast Cancer Cells & Marker for early cancer diagnosis & {$[28]$} & \\
\hline & miR-21 & Up-regulated & $\begin{array}{l}\text { Esophageal Squamous Cell } \\
\text { Carcinoma (ESCC) }\end{array}$ & - & [29] & \\
\hline 8 & miR-25 & Up-regulated & ESCC & Cell migration and Invasion directly & {$[30]$} & \\
\hline 9 & miR-17-92 & Up-regulated & $75 \%$ of ESCC & $\begin{array}{l}\text { Promote Cell Growth in vitro and } \\
\text { In vivo }\end{array}$ & {$[31]$} & \\
\hline 10 & miR-10b & Up-regulated & ESCC & Cell motility and Invasiveness & {$[32]$} & \multirow{6}{*}{$\begin{array}{l}\text { Esophageal } \\
\text { Squamous Cell } \\
\text { Carcinoma }\end{array}$} \\
\hline 11 & miR-196a & Up-regulated & ESCC & $\begin{array}{l}\text { Cell Proliferation and Anchorage } \\
\text { independent growth and Suppress } \\
\text { apoptosis }\end{array}$ & {$[33]$} & \\
\hline 12 & miR-145 & $\begin{array}{l}\text { FSCN1, novel target } \\
\text { gene for miR-145, } \\
\text { Upregulated }\end{array}$ & ESCC & $\begin{array}{l}\text { Extensive tumor and Lymphnode } \\
\text { metastasis and Poor prognosis }\end{array}$ & {$[34]$} & \\
\hline 13 & miR-19a & Down Regulated & ESCC & $\begin{array}{l}\text { Induce apoptosis in vitro and Impaired } \\
\text { Tumor Growth in vivo }\end{array}$ & {$[31]$} & \\
\hline 14 & miR-375 & Down-regulated & ESCC & Downregulates IGF1R & {$[35]$} & \\
\hline 15 & miR-205 & Down regulated & ESCC & $\begin{array}{l}\text { Increased Zinc Finger E-box binding } \\
\text { homeobox } 2\end{array}$ & {$[36]$} & \\
\hline 16 & miR-21 & Up-regulated & GC & $\begin{array}{l}\text { Oncomer in GC by inhibiting the tumor- } \\
\text { suppressor genes PDCD4 and PTEN }\end{array}$ & {$[37-39]$} & \multirow[t]{3}{*}{ Gastric Cancer } \\
\hline 17 & miR-106a & Up-regulated & GC & down regulate IL10 expression & {$[40]$} & \\
\hline 18 & miR-101 & Down Regulation & GC & $\begin{array}{l}\text { Induce COX2 expression which activates } \\
\text { activates the arachidonic acid/prostaglandin } \\
\text { E2 pathway following cell proliferation }\end{array}$ & [41] & \\
\hline
\end{tabular}

human cancers, it is highly expressed. It has strong control over PTEN, tropomysin-1, programmed cell death 4 and maspin that are regulators of survival, invasive and apoptosis [29].

\section{miR-106-25}

It is a polycistronic and found in chromosome 7q22.1. It encodes miR-25, 93 and miR-106b. It is found upregulaed in NSE and from which to BE and EAC. It is also shows potential cell development, anti-apoptotic as well as enhance the cell cycle in in vitro and in vivo tumorigenic activity [54]. miR-25 targets the E-cadherin gene at 3'UTR and enhances migration and cell invasion in ESCC. This miR-25 showed the oncogenic activity by inhibiting CDH1.

\section{miR-17-92}

miR-17-92, the oncomir- 1 , is a oncogenic miRNA $[55,56]$ found located in 13q31.3 and codes for miR-17, 18a, 19a, 20a, 19b-1 and miR-92-1. Its cluster found expressed about $75 \%$ in tumors of ESCC [31] and its expression enhances the cell growth in both in vitro and in vivo.

\section{miR-10b}

Its over expression was noticed in different cancer types [57-60] such as ESCC [32]. Its role in ESCC as inducing factor of invasiveness and motility of cell was noticed by Tian et al. [32]. A gene that suppress the migration of cell and invasiveness of the esophageal cancer was identified as KLF4, which is an miR10b target. 


\section{miR-196a}

In premalignant esophageal cancers tissues, its expression was found high as well as in different cancer types [33, 61-66]. In EC, Annexin A1 was targeted by this miRNA to suppress its function [65-67]. It function as factor of cell proliferating and factor of anchorage independent growth and thus inhibit the apoptosis.

\section{Tumor suppressor miR-375}

In EC, it function as PDK1 regulator (negative) and its promoter regions is hypermethylated adequately [68]. In mice, its role as inhibitors of motility of cell, proliferation of cell, formation of tumor, clonogenicity and metastasis was noticed. Its interaction with IGFIR 3' UTR often down regulates it and both are negatively correlated [35].

miR-145

It is induced by $p 53$, the tumor suppressor and it targets the c-Myc [69]. Another gene called FSCN1, which was expressed highly in ESCC (tumors) while not in normal epithelium, was also found recorded as target gene for this miRNA. The reduction in the prognosis and metastasis in lymphnode was found correlated with FSCN1 expression [34].

\section{Gastric cancer}

\section{Oncogenic miRNA}

\section{miR-21}

Its expression, compared to normal tissue, was found upregulated in GC [37-39] while it is inversely correlated with expression of PDCD4 [70-72]. It also targets the PTEN and hence perform as oncomer since it suppresses PDCD4 and PTEN in GC [73].

\section{miR-106a}

In GC, compared to normal tissues, it is found upregulated in various human tumors [74]. It reflect as G1-S transition positive regulator [74] and its binding with 3'UTR down regulates the cytokine such as IL10 in hematopoietic stem cells [40]. It was also regulated by SP1 and EGR1 for down regulating IL10 [40].

\section{Tumor suppressor miR-101}

In most of the cancers, the progression of cancer was due to epigenetic pathway dysregulation by inhibiting miR-101 and inducing EZHR over expression [75, 76]. Since, in GC, this miRNA targeting the COX2, its down regulation causes expression of $C O X 2$ [41] which controls the activation of prostaglandin E2 and arachidonic acid pathways.

\section{Let-7}

Its expression controls (reduce) the expression of RAS genes such as $H, K$ and NRAS. Its expression, compared to normal lung tissue, was found noticed low in lung tumor while inversely higher expression of RAS protein was noticed in lung tumor [77]. In gastric tumorigenesis $R A B 40 C$, which is a let-7a target, role was well recorded [78].

\section{miR-148}

It is found inactivated in GC by hypermethylating its promoter region [79] and this causes upregulation of DNA methyltransferase [79]. It act on the ROCK1 to down regulate it and tumor cell invasion [80].

\section{Lung cancer \\ Oncogenic miRNA miR-21}

It support the cell growth, invasiveness of tumor and metastasis [81] by suppressing the tumor suppressor genes. Its expression was found noticed high in mouse lung cancer (K-ras) dependent and controls the Spry1, Spry2, Btg2 and Pdcd4 by targeting the regulators of ERK/MEK/Ras [81-83]. It also act on the Apaf1, Fas1g, Pdcd4 and RhoB, the pro-apoptotic gene products, to apoptosis inhibition while PDCD4 directly associated with metastasis and invasion [83].

\section{miR-197}

Its knockdown results in induction of apoptosis and involved in $p 53$ pathway which causes uncontrolled cell proliferation [84].

miR-212

Table 2 Circulating microRNA expressions in different cancer cell/tumor

\begin{tabular}{|c|c|c|c|c|}
\hline S. NO. & miRNA & Cancer & Role & Author \\
\hline 1 & mir-375 & Low in OSCC patient plasma & Sensitive to Radiotherapy & [112] \\
\hline 2 & mir-125b & Low in OSCC patient plasma & Proliferation inhibition and migration & [113] \\
\hline 3 & mir-196 & $\begin{array}{l}\text { Over expressed in Head and neck } \\
\text { squamous cell carcinoma (HNSCC) }\end{array}$ & Resistance to Radiotherapy & [114] \\
\hline 4 & miR-150 & $\begin{array}{l}\text { Low expression in Esophageal } \\
\text { Squamous Cell Carcinoma }\end{array}$ & $\begin{array}{l}\text { Involved in tumor malignancy - metastasis in I } \\
\text { ymphnode, lymph invasion and low prognosis level }\end{array}$ & [115] \\
\hline 5 & mir-21 & $\begin{array}{l}\text { Over expression in Tongue } \\
\text { Sqamous Cell Carcinoma }\end{array}$ & Late stage marker and metastasis in Lymph node & [116] \\
\hline 6 & mir-134 & HNSCC & Metastasis & [117] \\
\hline 7 & mir-146a & High Concentration in OSCC & Increase in metastasis and Tumorogensis & [118] \\
\hline
\end{tabular}


Table 3 Exosomal microRNA expressions in different cancer cell/tumor

\begin{tabular}{lllll}
\hline S. NO. & miRNA & Cancer & Role & Author \\
\hline 1 & miR-200b & Colorectal Cancer & Increase proliferation & [119] \\
2 & miRNA-146b & Papillary Thyroid Cancer & Negative Proliferation & [120] \\
3 & miRNA-222 & Papillary Thyroid Cancer & Negative Proliferation & [120] \\
4 & miRNA-106b & Pancreatic Cancer & Promotes Gemcitabine Resistance & {$[121]$} \\
\hline
\end{tabular}

AChe level was found associated with rapid development of tumor and lower survival rate [85] since it was altered by this miRNA by acting at 3' UTR.

\section{miR-17-5p and miR-20a}

In lung cancers, its different types of miR-17-92 clusters were found highly expressed [86]. In lung cancer, that over express miR17-92, miR-17-5p and miR-20a is targeted for inducing the apoptosis [87].

\section{Tumor suppressor B-Cell Lymphocyte 2 (BCL2)}

It is known for its apoptosis regulation. Its over expression was found associated with cancer development and it also act as resistance exerting member against anticancer drugs or agents [88-90].

\section{miR-608}

Its upregulation was found recorded in mostly tissues [91] and its higher expression cause apoptosis [92]. It was proposed to have higher interaction with signaling pathways [93].

Mechanism for miRNA dysregulation The mechanisms by which over expression of miRNA were recorded in different cancer through following types,

Genomic abnormality Chromosomal aberration is associated with tumorigenesis. In humans [94] and mouse [95] occurrence of miRNA was recorded in regions or fragile sites associated with cancer. Different analytical tools revealed the existence of association between miRNA expression level and copy number variations [96-102].

Epigenetic factors In different cancer types, silence of tumor suppressor gene was due to $\mathrm{CpG}$ hypermethylation which also includes histone modifications [103].

Transcriptional regulation miRNA expression often associated with transcription factors also. In many cases, during differentiation, switching on of tissue specific miRNAs were activated by transcription factors which includes oncogenes and tumor suppressor gene. Its association was well documented in cancer.

Regulation at miRNA processing steps Processing efficiency and stability of precursors often help to maintain the level miRNA (mature) while its variation was noticed in mature miRNA and its precursor [104-111].

Circulating miRNA in Cancer Circulating miRNA play an important role in different cancer as prognostic as well as therapeutic markers (Table 2). Low level mir-375 and mir-125b expression were noticed in OSCC patients that are involved in radiotherapy and proliferation [112, 113]. Similarly, mir-196 was found highly expressed in Head and Neck sqamous cell carcinoma and caused resistance to radiotherapy [114]. In, Eosphoageal squamous cell carcinoma (SCC), miR-150 was found in low level which are involved in tumor malignancy such as metastasis and lymph node invasion [115]. Similarly, Tongue squamous cell carcinoma, mir-21 was found in high expression and was used as marker for late stage as well as metastasis in lymph node [116]. Mir-134 found involved in metastasis in HNSCC [117]. Higher expression level of mir-146a was noticed in OSCC that caused increased metastasis and tumorogenisis [118].

Exosomal miRNA in Cancer Exosomal miRNA are often involved in exchange of RNA (Table 3). miRNA$200 \mathrm{~b}$ was involved in increased proliferation in colorectal cancer [119]. Similarly, in Papillary thyroid cancer, negative proliferation was exerted by miRNA-146b and miRNA222 [120]. Chemotherapeutic drug, gemcitabine resistance to pancreatic cancer was induced by miRNA106b [121]. Thus, the exosomal miRNA involved in regulating cancer proliferation and conferring resistance to the cancer cells.

\section{Conclusion}

miRNA are the key biomarker in the field of cancer research. Its regulation describes the exact status like nature, development and its metastatic condition of the cancer. This review have discussed many such miRNA and emphasized the importance in the developmental cancer research. It could facilitate the early diagnosis and the therapeutic targets simultaneously for the greater reduction in cancer mortality. miRNA controlled signalling pathways portrays the precise key paths need to be focused for the treatment of cancer in efficient way. 


\section{Abbreviations}

miRNAs: MicroRNAs; mRNAs: Messanger RNAs; ncRNA: Non-coding RNA; UTR: Untranslated region; miRBase: miRNA database; DGCR8: DiGeorge critical region 8; Alu: Alanine; ssRNA: Single stranded RNA; Hox: Homeobox; HOXD10: Homeobox D10 gene; ER+: Estrogen receptor-positive; $\mathrm{PR}^{+}$: Progesterone Receptor; MCF7: Michigan cancer foundation-7; HBP1: HMG box-containing protein 1; let-7: lethal 7 gene; BT-IC: Breast tumor initiating cells; EMT: Epithelial-mesenchymal transition; ZEB1: Zinc finger Ebox-binding homeobox 1; ZEB2: Zinc finger E-box binding protein 2; EAC: Ehrlich ascites carcinoma; ESCC: Esophageal squamous cell carcinoma; 3' UTR: 3" untranslated regions; TPM1: Tropomyosin-1; PTEN: Phosphatase and tensin; PCD4: Programmed cell death 4; NSE: Neuron specific enolase levels; CDH: Cadherin; KLF4: Krüppel-like factor 4; ANXA1: Annexin A1; PDK1: 3-phosphoinositidedependent protein kinase-1; IGF1R: insulin-like growth factor 1 (IGF-1) receptor; FSCN1: Actin-binding protein, fascin homolog 1; IL: Interleukin; SP 1: Schwangerschafts-Protein; EGR1: Early growth response gene 1; EZH2: Enhancer of zeste homolog 2; COX: Cyclooxygenase; RAS: Reticular activating system; HRAS: Harvey rat sarcoma viral oncogene; KRAS: Kirsten rat sarcoma; NRAS: Neuroblastoma RAS Viral Oncogene; ROCK1: Rho-associated protein kinase 1; ERK: Extracellular signal-regulated kinase; AChE: Acetylcholinesterase; CGH: Comparative genomic hybridization; CpG: Cytosine (C)-phosphateguanine (G) in the DNA sequence.; HNSCC: Head and neck squamous cell carcinoma

\section{Acknowledgements}

Authors would like to extend their gratitude to the authorities of Bharathiar University and Head of the Department of Human Genetics and Molecular Biology, Bharathiar University, Coimbatore.

\section{Authors' contributions}

Authors Sindhuja SS and P.V. Sona prepared this manuscript; Dr.PVM corrected, aligned and checking the proof reading of this article. The author (s) read and approved the final manuscript.

\section{Funding}

There is no funding involvement for this review.

\section{Availability of data and materials}

The data given in this review were available with us in pdf and text.

\section{Ethics approval and consent to participate}

Since there is no involvement of human and their samples, ethical approval not needed for this work.

\section{Consent for publication}

Authors have not used any personal data included in this review.

\section{Competing interests}

Authors have no competent interest.

Received: 16 August 2019 Accepted: 31 May 2020

Published online: 12 July 2020

\section{References}

1. Hammond SM. An overview of microRNAs. Adv Drug Deliv Rev. 2015;87:314 https://doi.org/10.1016/j.addr.2015.05.001.

2. Mario A, Croce CM. MicroRNA in Cancer and cachexia-a mini-review. J Infect Dis. 2015;212(suppl 1):S74-7 https://doi.org/10.1093/infdis/jiv197.

3. Gianpiero DL, Garofalo M, Croce CM. MicroRNAs in cancer. Annu Rev Pathol Mech Dis. 2014;9(1):287-314 https://doi.org/10.1146/annurev-pathol-012513104715

4. Lee RC, Feinbaum RL, Ambros V. The C. elegans heterochronic gene lin-4 encodes small RNAs with antisense complementarity to lin-14. Cell. 1993;75: 843-54 PubMed: 8252621.

5. Reinhart BJ, Slack FJ, Basson M, Pasquinelli AE, Bettinger JC, et al. The 21nucleotide let-7 RNA regulates developmental timing in Caenorhabditis elegans. Nature. 2000;403:901-6 PubMed: 10706289.

6. Lagos-Quintana M, Rauhut R, Lendeckel W, Tuschl T. Identification of novel genes coding for small expressed RNAs. Science. 2001;294:853-8 PubMed: 11679670.
7. Lau NC, Lim LP, Weinstein EG, Bartel DP. An abundant class of tiny RNAs with probable regulatory roles in Caenorhabditis elegans. Science. 2001;294: 858-62 PubMed: 11679671.

8. Lee RC, Ambros V. An extensive class of small RNAs in Caenorhabditis elegans. Science. 2001;294:862-4 PubMed: 11679672.

9. Kozomara A, Griffiths-Jones S. miRBase: integrating microRNA annotation and deep-sequencing data. Nucleic Acids Res. 2011;39:D152-7 PubMed: 21037258.

10. Brock $\mathrm{H}$, Wang Z, Yang C. The role of microRNAs in metal carcinogeninduced cell malignant transformation and tumorigenesis. Food Chem Toxicol. 2016;98:58-65 https://doi.org/10.1016/j.fct.2016.02.012.

11. Lee Y, Kim M, Han J, Yeom KH, Lee S, et al. MicroRNA Genes Are Transcribed by RNA Polymerase II. EMBO J. 2004;23:4051-60 PubMed: 15372072.

12. Borchert GM, Lanier W, Davidson BL. RNA Polymerase III Transcribes Human microRNAs. Nat Struct Mol Biol. 2006:13:1097-101 PubMed: 17099701.

13. Lee Y, Ahn C, Han J, Choi H, Kim J, et al. The Nuclear RNase III Drosha Initiates microRNA Processing. Nature. 2003:425:415-9 PubMed: 14508493.

14. Denli AM, Tops BB, Plasterk RH, Ketting RF, Hannon GJ. Processing of Primary microRNAs by the Microprocessor Complex. Nature. 2004;432:231-5 PubMed: 15531879.

15. Gregory RI, Yan KP, Amuthan G, Chendrimada T, Doratotaj B, et al. The Microprocessor Complex Mediates the Genesis of microRNAs. Nature. 2004; 432:235-40 PubMed: 15531877.

16. Sun LY, Dutta A. MicroRNAs in cancer. Annu Rev Pathol. 2009;4(1):199-227 https://doi.org/10.1146/annurev.pathol.4.110807.092222.

17. Cai $\mathrm{X}$, Hagedorn $\mathrm{CH}$, Cullen BR. Human microRNAs Are Processed From Capped, Polyadenylated Transcripts That Can Also Function as mRNAs. Rna. 2004;10:1957-66 PubMed: 15525708.

18. Han J, Lee Y, Yeom KH, Nam JW, Heo I, et al. Molecular Basis for the Recognition of Primary microRNAs by the Drosha-DGCR8 Complex. Cell. 2006;125:887-901 PubMed: 16751099.

19. Bernstein E, Kim SY, Carmell MA, Murchison EP, Alcorn H, Li MZ, Mills AA, Elledge SJ, Anderson KV, Hannon GJ. Dicer is essential for mouse development. Nat Genet. 2003:35:215-7 PubMed: 14528307.

20. Wang Y, Medvid R, Melton C, Jaenisch R, Blelloch R. DGCR8 is essential for microRNA biogenesis and silencing of embryonic stem cell self-renewal. Nat Genet. 2007;39:380-5 PubMed: 17259983.

21. Park CY, Choi YS, McManus MT. Analysis of microRNA knockouts in mice. Hum Mol Genet. 2010;19:R169-75 PubMed: 20805106.

22. Vidigal JA, Ventura A. The biological functions of miRNAs: lessons from in vivo studies. Trends Cell Biol. 2015;25(3):137-47.

23. Ma L, Teruya-Feldstein J, Weinberg RA. Tumour invasion and metastasis initiated by microRNA-10b in breast cancer. Nature. 2007;449:682-688. PMID: 17898713; https://doi.org/10.1038/nature06174.

24. Chan JA, Krichevsky AM, Kosik KS. MicroRNA-21 is an antiapoptotic factor in human glioblastoma cells. Cancer Res. 2005;65:6029-6033. PMID:16024602; https://doi.org/10.1158/0008-5472.CAN-05-0137.

25. Li H, Bian C, Liao L, Li J, Zhao RC. miR-17-5p promotes human breast cancer cell migration and invasion through suppression of HBP1. Breast Cancer Res Treat. 2011;126:565-575. PMID:20505989; https://doi.org/10.1007/s10549010-0954-4.

26. Jelena R, Apostolos Z, Thomas V, Maria K, Demetrios AS, Efstathios NS. MicroRNA expression analysis in triple-negative (ER, PR and Her2/neu) breast cancer. Cell Cycle. 2011;10:10-2 PMID:21191182.

27. Chen J, Tian W, Cai H, He H, Deng Y. Downregulation of microRNA-200C is associated with drug resistance in human breast cancer. Med Oncol. 2011; 29:2527-2534. PMID: 22101791; https://doi.org/10.1007/s12032-011-0117-4.

28. Sempere LF, Christensen M, Silahtaroglu A, Bak M, Heath CV, Schwartz G, et al. Altered MicroRNA expression confined to specific epithelial cell subpopulations in breast cancer. Cancer Res. 2007;67:11612-11620. PMID: 18089790; https://doi.org/10.1158/0008-5472.CAN-07-5019.

29. Selcuklu SD, Donoghue MTA, Spillane C. miR-21 as a keyregulator of oncogenic processes. Biochem Soc Trans. 2009;37:918-25.

30. Xu X, Chen Z, Zhao X, et al. MicroRNA-25 promotes cell migration and invasion in esophageal squamous cell carcinoma. Biochem Biophys Res Commun. 2012;421(4):640-5.

31. Liu M, Wang Z, Yang S, et al. TNF-alpha is a novel target of miR- 19a. Int J Oncol. 2011;38(4):1013-22.

32. Tian Y, Luo A, Cai Y, Su Q, Ding F, Chen H, Liu Z. MicroRNA-10b promotes migration and invasion through KLF4 in human esophageal Cancer cell lines. J Biol Chem. 2010;285(11):7986-94. 
33. Luthra R, Singh RR, Luthra MG, et al. MicroRNA-196a targets annexin A1: a microRNA-mediated mechanism of annexin A1 downregulation in cancers. Oncogene. 2008;27(52):6667-78.

34. Hashimoto $Y$, Ito $T$, Inoue $H$, et al. Prognostic significance of fascin overexpression in human esophageal squamous cell carcinoma. Clin Cancer Res. 2005;11(7):2597-605.

35. Kong KL, Kwong DL, Chan TH, et al. MicroRNA-375 inhibits tumour growth and metastasis in oesophageal squamous cell carcinoma through repressing insulin-like growth factor 1 receptor. Gut. 2012;61(1):33-42.

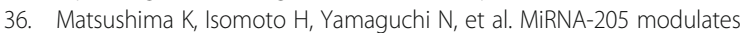
cellular invasion and migration via regulating zinc finger E-box binding homeobox 2 expression in esophageal squamous cell carcinoma cells. J Transl Med. 2011;9:30.

37. Li X, Zhang Y, Zhang H, Liu X, Gong T, Li M, Sun L, Ji G, Shi Y, Han Z, Han S, Nie Y, Chen X, Zhao Q, Ding J, Wu K, Daiming F. miRNA-223 promotes gastric cancer invasion and metastasis by targeting tumor suppressor EPB41L3. Mol Cancer Res. 2011;9:824-33 PMID: 21628394. https://doi.org/10. 1158/1541-7786.MCR-10-0529.

38. Inoue T, linuma H, Ogawa E, Inaba T, Fukushima R. Clinicopathological and prognostic significance of microRNA-107 and its relationship to DICER1 mRNA expression in gastric cancer. Oncol Rep. 2012;27:1759-64 PMID: 22407237. https://doi.org/10.3892/or.2012.1709.

39. Motoyama K, Inoue H, Mimori K, Tanaka F, Kojima K, Uetake H, Sugihara K, Mori M. Clinicopathological andprognostic significance of PDCD4 and microRNA-21 in human gastric cancer. Int J Oncol. 2010;36:1089-95 PMID: 20372781.

40. Sharma A, Kumar M, Aich J, Hariharan M, Brahmachari SK, Agrawal A, Ghosh B. Posttranscriptional regulation of interleukin-10 expression by hsa-miR106a. Proc Natl Acad Sci U S A. 2009;106:5761-6 PMID: 19307576. https:// doi.org/10.1073/pnas.0808743106.

41. He XP, Shao Y, Li XL, Xu W, Chen GS, Sun HH, Xu HC, Xu X, Tang D, Zheng $X F$, Xue YP, Huang GC, Sun WH. Downregulation of miR-101 in gastric cancer correlates with cyclooxygenase-2 overexpression and tumor growth. FEBS J. 2012;279:4201-12 PMID: 23013439. https://doi.org/10. 1111/febs.12013.

42. Zhang B, Pan $X$, Cobb GP, Anderson TA. microRNAs as oncogenes and tumor suppressors. Dev Biol. 2007;302:1-12. PMID: 16989803; https://doi.org/ 10.1016/j.ydbio.2006.08.028.

43. Moriarty $\mathrm{CH}$, Pursell B, Mercurio AM. miR-10b targets Tiam1: implications for Rac activation and carcinoma migration. J Biol Chem. 2010;285:2054120546. PMID: 20444703; https://doi.org/10.1074/jbc.M110.121012.

44. Liu Y, Zhao J, Zhang PY, Zhang Y, Sun SY, Yu SY, et al. MicroRNA-10b targets E-cadherin and modulates breast cancer metastasis. Med Sci Monit. 2012;18:BR299-308 PMID:22847191.

45. Han M, Liu M, Wang Y, Mo Z, Bi X, Liu Z, et al. Re-expression of miR-21 contributes to migration and invasion by inducing epithelial-mesenchymal transition consistent with cancer stem cell characteristics in MCF-7 cells. Mol Cell Biochem. 2012;363:427-436. PMID:22187223; https://doi.org/10.1007/ s11010-011-1195-5.

46. Han M, Liu M, Wang Y, Chen X, Xu J, Sun Y, et al. Antagonism of miR-21 reverses epithelial-mesenchymal transition and cancer stem cell phenotype through AKT/ERK1/2 inactivation by targeting PTEN. PLoS One. 2012;7: e39520. PMID: 22761812; https://doi.org/10.1371/journal.pone.0039520.

47. Iorio MV, Ferracin M, Liu CG, Veronese A, Spizzo R, Sabbioni S, et al. MicroRNA gene expression deregulation in human breast cancer. Cancer Res. 2005;65:7065-7070. PMID: 16103053; https://doi.org/10.1158/0008-5472. CAN-05-1783.

48. Fassina A, Marino F, Siri M, Zambello R, Ventura L, Fassan M, et al. The miR17-92 microRNA cluster: a novel diagnostic tool in large B-cell malignancies. Lab Investig. 2012;92:1574-1582. PMID: 22964854; https://doi.org/10.1038/ labinvest.2012.129

49. Reinhart BJ, Slack FJ, Basson M, Pasquinelli AE, Bettinger JC, Rougvie AE, et al. The 21-nucleotide let-7 RNA regulates developmental timing in Caenorhabditis elegans. Nature. 2000;403:901-906. PMID: 10706289; https:// doi.org/10.1038/35002607.

50. Park SM, Gaur AB, Lengyel E, Peter ME. The miR- 200 family determines the epithelial phenotype of cancer cells by targeting the E-cadherin repressors ZEB1 and ZEB2. Genes Dev. 2008;22:894-907. PMID: 18381893; https://doi. org/10.1101/gad.1640608.

51. Korpal M, Lee ES, Hu G, Kang Y. The miR-200 family inhibits epithelialmesenchymal transition and cancer cell migration by direct targeting of $E$ - cadherin transcriptional repressors ZEB1 and ZEB2. J Biol Chem. 2008;283: 14910-14914. PMID: 18411277; https://doi.org/10.1074/jbc.C800074200.

52. Gregory PA, Bert AG, Paterson EL, Barry SC, Tsykin A, Farshid G, et al. The miR-200 family and miR-205 regulate epithelial to mesenchymal transition by targeting ZEB1 and SIP1. Nat Cell Biol. 2008;10:593-601. PMID: 18376396; https://doi.org/10.1038/ncb1722.

53. Ramesh S, Mo Y-Y. Role of microRNAs in breast Cancer. Cancer Biol Ther. 2013;14(3):201-12 https://doi.org/10.4161/cbt.23296.

54. Kan T, Sato F, Ito T, et al. The miR-106b-25 Polycistron, activated by genomic amplification, functions as an oncogene by suppressing p21 and Bim. Gastroenterol. 2009;136(5):1689-700.

55. He L, Thomson JM, Hemann MT, et al. A microRNA polycistron as a potential human oncogene. Nature. 2005;435(7043):828-33.

56. Olive V, Jiang I, He L. Mir-17-92, a cluster of miRNAs in the midst of the cancer network. Int J Biochem Cell Biol. 2010:42(8):1348-54.

57. Ladeiro Y, Couchy G, Balabaud C, et al. MicroRNA profiling in hepatocellular tumors is associated with clinical features and oncogene/tumor suppressor gene mutations. Hepatology. 2008;47(6):1955-63.

58. O'Day E, Lal A. MicroRNAs and their target gene networks in breast cancer. Breast Cancer Res. 2010;12(2):201

59. Sasayama T, Nishihara M, Kondoh T, Hosoda K, Kohmura E. MicroRNA-10b is overexpressed in malignant glioma and associated with tumor invasive factors, uPAR and RhoC. Int J Cancer. 2009;125(6):1407-13.

60. Garzon R, Garofalo M, Martelli MP, et al. Distinctive microRNA signature of acute myeloid leukemia bearing cytoplasmic mutated nucleophosmin. Proc Nat Acad Sci USA. 2008;105(10):3945-50.

61. Maru DM, Singh RR, Hannah C, et al. MicroRNA-196a is a potential marker of progression during Barrett's metaplasia-dysplasia-invasive adenocarcinoma sequence in esophagus. Am J Pathol. 2009;174(5):1940-8.

62. Schimanski CC, Frerichs K, Rahman F, et al. High miR-196a levels promote the oncogenic phenotype of colorectal cancer cells. World J Gastroenterol. 2009:15(17):2089-96.

63. Zhang Y, Li M, Wang $\mathrm{H}$, et al. Profiling of 95 microRNAs in pancreatic cancer cell lines and surgical specimens by real-time PCR analysis. World J Surg. 2009;33(4):698-709.

64. Hui $A B$, Shi W, Boutros $P C$, et al. Robust global micro-RNA profiling with formalin-fixed paraffin-embedded breast cancer tissues. Lab Investig. 2009; 89(5):597-606.

65. Paweletz CP, Ornstein DK, Roth MJ, et al. Loss of annexin 1 correlates with early onset of tumorigenesis in esophageal and prostate carcinoma. Cancer Res. 2000;60(22):6293-7.

66. Xia SH, Hu LP, Hu H, et al. Three isoforms of annexin I are preferentially expressed in normal esophageal epithelia but downregulated in esophagea squamous cell carcinomas. Oncogene. 2002;21(43):6641-8.

67. Hu N, Flaig MJ, Su H, et al. Comprehensive characterization of annexin I alterations in esophageal squamous cell carcinoma. Clin Cancer Res. 2004; 10(18 Pt 1):6013-22.

68. Li X, Lin R, Li J. Epigenetic silencing of microRNA-375 regulates PDK1 expression in esophageal cancer. Dig Dis Sci. 2011;56(10):2849-56.

69. Sachdeva M, Zhu S, Wu F, et al. p53 represses c-Myc through induction of the tumor suppressor miR-145. Proc Natl Acad Sci U S A. 2009;106(9):3207-12.

70. Cao Z, Yoon JH, Nam SW, Lee JY, Park WS. PDCD4 expression inversely correlated with miR-21 levels in gastric cancers. J Cancer Res Clin Oncol. 2012;138:611-9 PMID: 22212233. https://doi.org/10.1007/s00432-011-1140-8.

71. Hiyoshi $Y$, Kamohara H, Karashima R, Sato N, Imamura Y, Nagai Y, Yoshida N, Toyama E, Hayashi N, Watanabe M, Baba H. MicroRNA-21 regulates the proliferation and invasion in esophageal squamous cell carcinoma. Clin Cancer Res. 2009;15:1915-22 PMID: 19276261. https://doi.org/10.1158/10780432.CCR-08-2545.

72. Lu Z, Liu M, Stribinskis V, Klinge CM, Ramos KS, Colburn NH, Li Y. MicroRNA21 promotes cell transformation by targeting the programmed cell death 4 gene. Oncogene. 2008;27:4373-9 PMID: 18372920. https://doi.org/10.1038/ onc.2008.72.

73. Zhang BG, Li JF, Yu BQ, Zhu ZG, Liu BY, Yan M. microRNA-21 promotes tumor proliferation and invasion in gastric cancer by targeting PTEN. Oncol Rep. 2012;27:1019-26 PMID: 22267008. https://doi.org/10.3892/or.2012.1645.

74. Ivanovska I, Ball AS, Diaz RL, Magnus JF, Kibukawa M, Schelter JM, Kobayashi SV, Lim L, Burchard J, Jackson AL, Linsley PS, Cleary MA. MicroRNAs in the miR-106b family regulate p21/CDKN1A and promote cell cycle progression. Mol Cell Biol. 2008:28:2167-74 PMID: 18212054. https://doi.org/10.1128/MCB. 01977-07 
75. Varambally S, Cao Q, Mani RS, Shankar S, Wang X, Ateeq B, Laxman B, Cao X, Jing X, Ramnarayanan K, Brenner JC, Yu J, Kim JH, Han B, Tan P, KumarSinha C, Lonigro RJ, Palanisamy N, Maher CA, Chinnaiyan AM. Genomic loss of microRNA-101 leads to overexpression of histone methyltransferase EZH2 in cancer. Science. 2008;322:1695-9 PMID: 19008416. https://doi.org/10. 1126/science.1165395

76. Carvalho J, van Grieken NC, Pereira PM, Sousa S, Tijssen M, Buffart TE, Diosdado B, Grabsch H, Santos MA, Meijer G, Seruca R, Carvalho B, Oliveira C. Lack of microRNA-101 causes E-cadherin functional deregulation through EZH2 up-regulation in intestinal gastric cancer. J Pathol. 2012;228:31-44 PMID: 22450781. https://doi.org/10.1002/path.4032.

77. Johnson SM, Grosshans H, Shingara J, Byrom M, Jarvis R, Cheng A, Labourier E, Reinert KL, Brown D, Slack FJ. RAS is regulated by the let-7 microRNA family. Cell. 2005;120:635-47 PMID: 15766527. https://doi.org/10.1016/j.cell.2005.01.014.

78. Yang Q, Jie Z, Cao H, Greenlee AR, Yang C, Zou F, Jiang Y. Low-level expression of let-7a in gastric cancer and its involvement in tumorigenesis by targeting RAB40C. Carcinogenesis. 2011;32:713-22 PMID: 21349817. https://doi.org/10.1093/carcin/bgr035.

79. Zhu A, Xia J, Zuo J, Jin S, Zhou H, Yao L, Huang H, Han Z. MicroRNA-148a is silenced by hypermethylation and interacts with DNA methyltransferase 1 in gastric cancer. Med Oncol. 2012;29:2701-9 PMID: 22167392. https://doi. org/10.1007/s12032-011-0134-3.

80. Zheng B, Liang L, Wang C, Huang S, Cao X, Zha R, Liu L, Jia D, Tian Q, Wu J, Ye Y, Wang Q, Long Z, Zhou Y, Du C, He X, Shi Y. MicroRNA-148a suppresses tumor cell invasion and metastasis by downregulating ROCK1 in gastric cancer. Clin Cancer Res. 2011;17:7574-83 PMID: 21994419. https:// doi.org/10.1158/1078-0432.CCR-11-1714.

81. Zhu S, Wu H, Wu F, Nie D, Sheng S, Mo YY. MicroRNA-21 targets tumor suppressor genes in invasion and metastasis. Cell Res. 2008;18:350-9 PubMed: 18270520

82. Hatley ME, Patrick DM, Garcia MR, et al. Modulation of K-Ras-dependent lung tumorigenesis by microRNA-21. Cancer Cell. 2010;18:282-93 PubMed 20832755.

83. Lu Z, Liu M, Stribinskis $V$, et al. MicroRNA-21 promotes cell transformation by targeting the programmed cell death 4 gene. Oncogene. 2008;27:4373-9 PubMed: 18372920.

84. Fiori ME, Barbini C, Haas TL, et al. Antitumor effect of miR-197 targeting in p53 wild-type lung cancer. Cell Death Differ. 2014;21(5):774-82.

85. Zhao $Y$, Wang $X$, Wang $T$, et al. Acetylcholinesterase, a key prognostic predictor for hepatocellular carcinoma, suppresses cell growth and induces chemosensitization. Hepatology. 2011;53(2):493-503.

86. Hayashita $Y$, Osada H, Tatematsu Y, et al. A polycistronic MicroRNA cluster, miR-17-92, is overexpressed in human lung cancers and enhances cell proliferation. Cancer Res. 2005;65(21):9628-32.

87. Matsubara $H$, Takeuchi T, Nishikawa E, et al. Apoptosis induction by antisense oligonucleotides against miR-17-5p and miR-20a in lung cancers overexpressing miR-17-92. Oncogene. 2007;26(41):6099-105.

88. Fisher TC, Milner AE, Gregory CD, et al. BCl-2 modulation of apoptosis induced by anticancer drugs: resistance to thymidylate stress is independent of classical resistance pathways. Cancer Res. 1993;53(14):3321-6.

89. Miyashita T, Reed JC. BCl-2 oncoprotein blocks chemotherapy-induced apoptosis in a human leukemia cell line. Blood. 1993;81(1):151-7.

90. Tang C, Willingham MC, Reed JC, et al. High levels of p26BCL-2 oncoprotein retard taxol-induced apoptosis in human pre-B leukemia cells. Leukemia. 1994:8(11):1960-9.

91. Soini $Y$, Kinnula V, Kaarteenaho-Wiik R, Kurttila E, Linnainmaa K, Paakko P. Apoptosis and expression of apoptosis regulating proteins bcl-2, $\mathrm{mcl}-1, \mathrm{bcl}-$ X, and bax in malignant mesothelioma. Clin Cancer Res. 1999;5(11):3508-15.

92. Othman N, In LLA, Harikrishna JA, Hasima N. BCl-xL silencing induces alterations in hsa-miR-608 expression and subsequent cell death in A549 and SK-LU1 human lung adenocarcinoma cells. PLOS ONE. 2013;8(12):e81735.

93. Norahayu $\mathrm{O}, \mathrm{Nagoor} \mathrm{NH}$. The role of microRNAs in the regulation of apoptosis in lung cancer and its application in cancer treatment. Biomed Res Int. 2014;2014:1-19 https://doi.org/10.1155/2014/318030.

94. Calin GA, Sevignani C, Dumitru CD, Hyslop T, Noch E, et al. Human microRNA Genes Are Frequently Located at Fragile Sites and Genomic Regions Involved in Cancers. Proc Natl Acad Sci U S A. 2004;101:2999-3004 PubMed: 14973191.

95. Sevignani C, Calin GA, Nnadi SC, Shimizu M, Davuluri RV, et al. MicroRNA Genes Are Frequently Located Near Mouse Cancer Susceptibility Loci. Proc Natl Acad Sci U S A. 2007;104:8017-22 PubMed: 17470785.
96. Porkka KP, Pfeiffer MJ, Waltering KK, Vessella RL, Tammela TL, Visakorpi T. MicroRNA Expression Profiling in Prostate Cancer. Cancer Res. 2007;67:61305 PubMed: 17616669.

97. Zhang L, Huang J, Yang N, Greshock J, Megraw MS, et al. microRNAs Exhibit High Frequency Genomic Alterations in Human Cancer. Proc Natl Acad Sci U S A. 2006;103:9136-41 PubMed: 16754881.

98. Tagawa H, Karube K, Tsuzuki S, Ohshima K, Seto M. Synergistic Action of the microRNA-17 Polycistron and Myc in Aggressive Cancer Development. Cancer Sci. 2007;98:1482-90 PubMed: 17608773.

99. Rinaldi A, Poretti G, Kwee I, Zucca E, Catapano CV, et al. Concomitant MYC and microRNA Cluster miR-17-92 (C13orf25) Amplification in Human Mantle Cell Lymphoma. Leuk Lymphoma. 2007:48:410-2 PubMed: 17325905.

100. Welch C, Chen Y, Stallings RL. MicroRNA-34a Functions as a Potential Tumor Suppressor by Inducing Apoptosis in Neuroblastoma Cells. Oncogene. 2007; 26:5017-22 PubMed: 17297439.

101. Hayashita Y, Osada H, Tatematsu Y, Yamada H, Yanagisawa $K$, et al. A Polycistronic microRNA Cluster, miR-17-92, Is Overexpressed in Human Lung Cancers and Enhances Cell Proliferation. Cancer Res. 2005;65:9628-32 PubMed: 16266980.

102. Tagawa H, Seto M. A microRNA Cluster as a Target of Genomic Amplification in Malignant Lymphoma. Leukemia. 2005;19:2013-6 PubMed: 16167061.

103. Lehmann U, Hasemeier B, Christgen M, Muller M, Romermann D, et al. Epigenetic Inactivation of microRNA Gene hsa-mir-9-1 in Human Breast Cancer. J Pathol. 2008;214:17-24 PubMed: 17948228.

104. Shah YM, Morimura K, Yang Q, Tanabe T, Takagi M, Gonzalez FJ. Peroxisome Proliferator-Activated Receptor Alpha Regulates a microRNA-mediated Signaling Cascade Responsible for Hepatocellular Proliferation. Mol Cell Biol. 2007;27:4238-47 PubMed: 17438130.

105. Mott JL, Kobayashi S, Bronk SF, Gores GJ. mir-29 Regulates Mcl-1 Protein Expression and Apoptosis. Oncogene. 2007;26:6133-40 PubMed: 17404574.

106. Kluiver J, van den Berg A, de Jong D, Blokzijl T, Harms G, et al. Regulation of pri-microRNA BIC Transcription and Processing in Burkitt Lymphoma. Oncogene. 2007;26:3769-76 PubMed: 17173072

107. Lee EJ, Baek M, Gusev Y, Brackett DJ, Nuovo GJ, Schmittgen TD. Systematic Evaluation of microRNA Processing Patterns in Tissues, Cell Lines, and Tumors. RNA. 2007;14:35-42 PubMed: 18025253.

108. Obernosterer G, Leuschner PJ, Alenius M, Martinez J. Post-transcriptional Regulation of microRNA Expression. RNA. 2006;12:1161-7 PubMed: 16738409.

109. Michael MZ, OC SM, van Holst Pellekaan NG, Young GP, James RJ. Reduced Accumulation of Specific microRNAs in Colorectal Neoplasia. Mol Cancer Res. 2003;1:882-91 PubMed: 14573789.

110. Lu Y, Thomson JM, Wong HY, Hammond SM, Hogan BL. Transgenic OverExpression of the microRNA miR-17-92 Cluster Promotes Proliferation and Inhibits Differentiation of Lung Epithelial Progenitor Cells. Dev Biol. 2007; 310:442-53 PubMed: 17765889.

111. Mineno J, Okamoto S, Ando T, Sato M, Chono H, et al. The Expression Profile of microRNAs in Mouse Embryos. Nucleic Acids Res. 2006:34:1765-71 PubMed: 16582102.

112. Yan $Y$, et al. Circulating miRNAs as biomarkers for oral squamous cell carcinoma recurrence in operated patients. Oncotarget. 2017;8(5):8206-14.

113. Shiiba $M$, et al. MicroRNA-125b regulates proliferation and radioresistance of oral squamous cell carcinoma. Br J Cancer. 2013;108(9):1817-21.

114. Suh YE, et al. MicroRNA-196a promotes an oncogenic effect in head and neck cancer cells by suppressing annexin $\mathrm{A} 1$ and enhancing radioresistance. Int J Cancer. 2015;137(5):1021-34.

115. Yokobori T, et al. MiR-150 is associated with poor prognosis in esophagea squamous cell carcinoma via targeting the EMT inducer ZEB1. Cancer Sci. 2013;104(1):48-54.

116. Li J, et al. MiR-21 indicates poor prognosis in tongue squamous cell carcinomas as an apoptosis inhibitor. Clin Cancer Res. 2009;15(12): 3998-4008.

117. Liu CJ, et al. miR-134 induces oncogenicity and metastasis in head and neck carcinoma through targeting WWOX gene. Int. J. Cancer. 2014;134(4):811-21.

118. Hung PS, et al. miR-146a enhances the oncogenicity of oral carcinoma by concomitant targeting of the IRAK1, TRAF6 and NUMB genes. PLoS One. 2013;8(11):79926.

119. Zhang Z, Xingb T, Chenc Y, Xiaod J. Exosome-mediated miR-200b promotes colorectal cancer proliferation upon TGF- $\beta 1$ exposure. Biomed Pharmacother. 2018;106(2018):1135-43. 
120. Lee JC, Gundara J, Serpell J, Bach LA. Papillary thyroid cancer-derived exosomes contain miRNA-146b and miRNA-222. J Surg Res. 2015; 196(1):39-48.

121. Fang $Y$, Zhou W, Rong Y, Kuang T, Xu X, Wu W, Wang D, Lou W. Exosomal miRNA-106b from cancer-associated fibroblast promotes gemcitabine resistance in pancreatic cancer. Exp Cell Res. 2019;383:111543.

\section{Publisher's Note}

Springer Nature remains neutral with regard to jurisdictional claims in published maps and institutional affiliations.

Ready to submit your research? Choose BMC and benefit from:

- fast, convenient online submission

- thorough peer review by experienced researchers in your field

- rapid publication on acceptance

- support for research data, including large and complex data types

- gold Open Access which fosters wider collaboration and increased citations

- maximum visibility for your research: over $100 \mathrm{M}$ website views per year

At BMC, research is always in progress.

Learn more biomedcentral.com/submissions 